\title{
Hilling of Transplanted Seedlings from Novel Hybrid True Potato Seeds Does Not Enhance Tuber Yield but Can Affect Tuber Size Distribution
}

\author{
Luuk C. M. van Dijk ${ }^{1,2}$ (D) Willemien J. M. Lommen ${ }^{1}$. \\ Michiel E. de Vries ${ }^{2}$ (D) Olivia C. Kacheyo ${ }^{2}$ (D) Paul C. Struik ${ }^{1}$ (D)
}

Received: 28 May 2020 / Accepted: 30 September 2020/ Published online: 19 November 2020

(C) The Author(s) 2020

\begin{abstract}
A novel cropping system for potato was tested for two consecutive years under normal Dutch agronomic conditions. Seedlings from two experimental genotypes of hybrid true potato seeds were produced in a greenhouse nursery and transplanted into the field 5 weeks after sowing to assess tuber yield levels and to study effects of hilling on tuber yield and number, tuber size distribution and tuber greening. Field experiments had a split-plot design with hilling treatments as the main plots and genotypes as the subplots. Final harvest was at 122 and 132 days after transplanting in 2017 and 2018, respectively. Hybrid seedlings were transplanted into small initial ridges and irrigated straight after planting. Three hilling treatments were applied between transplanting and $100 \%$ canopy cover. Treatment 'zero hilling' did not receive any additional hilling after transplanting. Treatments 'double hilling' and 'triple hilling' received two and three additional hilling treatments, respectively. Total tuber yields at final harvest in both years were not affected by the hilling treatments. Yields for the respective genotypes were 26 and $30 \mathrm{Mg} / \mathrm{ha}$ in 2017 and 25 and $32 \mathrm{Mg} / \mathrm{ha}$ in 2018 . Total tuber numbers were only affected by hilling treatments in 2017, where under hilled conditions, plants produced more tubers compared with plants under zero hilling. Plants under zero hilling yielded more tubers in size class $>40 \mathrm{~mm}$ compared with triple hilling in 2017. In 2018, no significant effects of hilling on tuber numbers were found, but the trend was similar to that in 2017.
\end{abstract}

Keywords Greenhouse nursery $\cdot$ Hilling $\cdot$ Hybrid potato cultivation systems $\cdot$ Solanum tuberosum . Transplanting hybrid seedlings $\cdot$ True potato seed

Electronic supplementary material The online version of this article (https://doi.org/10.1007/s11540-02009481-x) contains supplementary material, which is available to authorized users.

Luuk C. M. van Dijk

luuk.vandijk@wur.nl

Extended author information available on the last page of the article 


\section{Introduction}

The introduction of hybrid breeding at the diploid level in potato (Solanum tuberosum L.) will revolutionize the methods applied by potato breeders in the near future (Stokstad 2019) and subsequently will drastically alter potato multiplication practices (Jansky et al. 2016). The ability to produce diploid inbred lines (Lindhout et al. 2011) allows breeders to make full use of available tools in modern plant breeding and genetics (Bethke et al. 2019). Hybrid breeding accelerates the process of introducing desired traits into the breeding material to improve potato yields, pathogen resistances and tuber quality aspects. Additionally, it enhances the possibilities for combining traits of interest in one new cultivar. In that way, hybrid breeding can respond faster to changing market trends than conventional potato breeding.

A cross between two homozygous parents results in F1 botanical potato seeds, commonly called true potato seeds (TPS), that are genetically identical (Bachem et al. 2019). These hybrid true seeds may transform the propagation of potatoes throughout north-western Europe and North America (Jansky et al. 2016; Stokstad 2019). In the past, open-pollinated (OP) TPS was studied as a technology to provide disease-free starting material, especially suitable for small-scale farmers in remote regions where access to certified quality seed tubers was limited (Wiersema 1984; Almekinders et al. 1996). It was suggested that OP-TPS could be used in different systems: in a nursery setting, OP-TPS might produce transplants, seedling tubers or ware tubers; in a field setting, OP-TPS can be directly sown to produce seedling or ware tubers. Transplanted seedlings and seedling tubers were seen as intermediate steps in the production of seed tubers or ware (Almekinders et al. 1996). However, being highly heterogenous, the OPTPS was considered unsuitable for large potato processing markets working only with the most uniform cultivars. The homogeneity of hybrid TPS is a favourable characteristic for highly mechanized potato value chains with high-quality standards. Therefore, hybrid TPS could become the foundation of novel potato planting materials at the start of new high-tech potato cropping systems (Edelenbosch and Munnichs 2020).

Using hybrid TPS could significantly decrease the number of vegetative multiplication cycles of seed tubers in the field or might even make vegetative multiplication unnecessary. In Fig. 1, potential cultivation pathways using hybrid TPS are suggested for mechanized temperate cropping conditions like the Netherlands. In the first season, hybrid TPS, produced under greenhouse conditions, could be either sown in a greenhouse cultivation system or directly in the field. When sown in a greenhouse cultivation system, either seedling tubers could be produced or seedlings for transplanting into the field. When hybrid TPS is sown directly in the field, it might produce either seedling tubers or even ware tubers. This also applies for TPS seedlings transplanted into the field. In the second season, seedling tubers can be grown in the field to produce either seed tubers or ware tubers; thereafter, the seed tubers can be used to produce ware tubers in the third season. Thus, after sowing of hybrid TPS, ware tubers can be harvested in one to three seasons, following the proposed cultivation pathways of Fig. 1.

At present, little is known about the field performance of different types of hybrid TPS planting materials. Under temperate conditions, the major uncertainties are seedling (tuber) vigour and yields of hybrid cultivars. In a yield study with hybrid seedling tubers (derived from hybrid transplanted seedlings) as planting material, the highest yielding hybrids reached similar levels to the lowest yielding commercial cultivars 


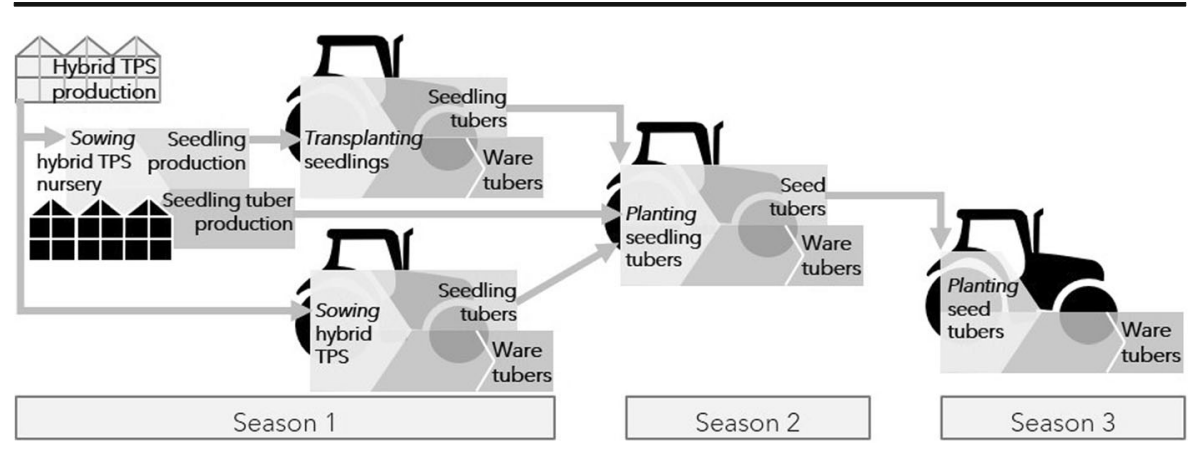

Fig. 1 Possible cultivation pathways for ware tuber production from hybrid true potato seeds (TPS). All cultivation pathways start at the top left with greenhouse production of hybrid TPS and end with a field harvest of ware tubers in Season 1, 2 or 3. Hybrid TPS is sown either in a greenhouse nursery (middle left) or directly in the field (bottom left). In the greenhouse nursery either seedlings for field transplanting are produced or seedling tubers (first generation) to plant in the field next season. Field transplanted seedlings and field-sown hybrid TPS can produce seedling tubers (first generation) or ware tubers. Produced seedling tubers are planted in Season 2 for production of seed tubers (second generation) or ware tubers. Seed tubers are planted in Season 3 to produce ware tubers. In the greenhouse, the seedling production period is shorter compared with the seedling tuber production period. In the field, the seed(ling) tuber production period is shorter than the ware tuber production period

grown from seed tubers (Stockem et al. 2020). De Vries et al. (2016) showed that the yield of transplanted hybrid seedlings in tropical conditions was $29 \mathrm{Mg} / \mathrm{ha}$ for the best performing hybrid. The yield level of a hybrid potato crop grown from transplanted seedlings under temperate conditions has not yet been documented. The research in this study focuses on crops from these transplanted seedlings, derived from hybrid seeds sown in a greenhouse nursery.

Transplanting of seedlings raised in a greenhouse nursery is a common practice for many other vegetable crops like lettuce, cabbage and leek in highly mechanized and automated cropping systems in north-western Europe and North America (Frantz et al. 1998; Kerbiriou et al. 2013; Yamamoto et al. 2016; Xie and Kristensen 2017). Using transplanted seedlings advances the growing period at the start of the crop cycle compared with direct field sowing and allows optimization of the conditions during germination and early growth which is the most sensitive period for the seedlings. As a result, very vigorous plantlets are transplanted into the field, which might have a competitive advantage against early weeds (Kerbiriou et al. 2013). Despite the success of mechanical transplanting in vegetables, there are also disadvantages such as transplant shock caused, for example, by mechanical root damage of the transplanted seedlings and plantlets (Kerbiriou et al. 2013) and often leading to a delay in growth (Engels et al. 1994, 1995; Lommen 1999; Tadesse et al. 2001a; Almekinders et al. 2010). Suitable methods to transplant and cultivate potato hybrid seedlings under temperate (Dutch) agronomic conditions have not yet been studied.

One of the first decisions to make when growing new types of crops is to decide on a cultivation and planting system. In conventional potato production in north-western Europe, it is common practice to plant the seed tuber in a ridge just below ground level (Van der Zaag 1999) after which the ridge is earthed up into a large ridge (about $20 \mathrm{~cm}$ height from ground level). Growing potatoes in ridge systems facilitates harvesting by large, high-tech potato harvesters. Moreover, soil temperature increases faster at the start of the season in a ridge system than in a flat, non-hilled field, due to the increased 
soil surface area and better exposure to the sun (Shaw and Buchele 1957; Burrows 1963). Ridges are also beneficial in preventing water-logged conditions for the tubers and allow the plants to position daughter tubers well covered in the soil. Good soil coverage of tubers has a yield advantage (Carling and Walworth 1990) and prevents greening of tubers (Carling and Walworth 1990; Kouwenhoven et al. 2003; Mikitzel 2014). Larger ridges, combined with deeper planting, have a positive effect on total tuber yield, due to a higher number of large-sized tubers per plant (Kouwenhoven 1970).

Due to the aforementioned reasons, it might be advantageous to transplant a hybrid potato seedling into a ridge. However, the slower growth rate of the young seedlings compared with conventional seed tubers, and the lack of a large starchy storage organ as additional source of nutrients and energy reserves, makes it necessary to transplant the seedlings with their roots and basal part of the stem shallow in a small ridge. This allows the seedling to make use of its leaf area for photosynthetic activity. Additional hilling should be carried out later in the growing period to maximize the advantages of a common potato ridge. Experiments in a different setting, carried out with directly sown OP-TPS seedlings in a bed system, showed that adding extra substrate resulted in more stolons per plant and an increased tuber number per plant compared with not adding substrate (Wiersema 1984). The effects of hilling the potato ridge on yield and tuber size distribution of transplanted hybrid seedlings in Dutch, highly mechanized, field conditions are not yet known.

Experiments were done in two years, in which hybrid seedlings, raised in a greenhouse nursery, were transplanted into the field and exposed to different hilling treatments. This research aimed to study: (1) whether hilling of the ridge has an effect on tuber fresh weight, tuber number, tuber size distribution, tuber dry-matter percentage and tuber greening; and (2) whether hybrid transplants derived from a greenhouse nursery are able to achieve reasonable yields under normal Dutch potato cultivation practices.

\section{Materials and Methods}

\section{Hybrid Potato Genotypes}

Two experimental hybrids were used, coded H03 and H04. The hybrid TPS were obtained from the Dutch potato breeding company Solynta. At the start of the experiments, little information was available about the characteristics of these genotypes. It was reported that both genotypes were able to produce reasonable tuber yields in a greenhouse pot trial (Solynta, personal communication 2016). Two genotypes were used for the sake of security, to be able to deal with unexpected growth behaviour of the genetic material in the field trials.

\section{Production of Seedlings}

The hybrid true seeds were sown 5 weeks prior to field transplanting in 104-plug trays $(32 \times 52 \mathrm{~cm}$, Horticoop, Bleiswijk) with cells of $2.5 \times 2.5 \times 3.8 \mathrm{~cm}(w \times l \times h)$ filled with $23.75 \mathrm{ml}$ peat moss substrate. One seed was sown by hand on top of the substrate. 
Seedlings were grown for 4 weeks in a greenhouse nursery at $75 \%$ relative humidity, with day/night temperature set at $18 / 16{ }^{\circ} \mathrm{C}$, and a 16 -h photoperiod ensured by Son- $\mathrm{T}$ $600 \mathrm{~W}$ lamps which switched on when radiation dropped below $120 \mathrm{~W} \mathrm{~m}^{-2}$. Seedlings were irrigated every second day to avoid water-limiting conditions. Four weeks after sowing, the nursery trays were placed in a screenhouse with open sides for a 1-week hardening-off period. Selection of usable transplants was carried out 1 day prior to transplanting using the following criteria: aboveground height between 7 and $12 \mathrm{~cm}$ with 5 to 8 fully developed leaves.

\section{Substrate and Irrigation}

The substrate contained as main components $30 \%$ fine Swedish sphagnum peat moss, $50 \%$ coir fibre and $20 \%$ crude perlite. Per cubic meter volume the following nutrients were added: $0.3 \mathrm{~kg}$ calcium nitrate $\left(14.4 \% \mathrm{~N}^{-N_{3}}, 1.1 \% \mathrm{~N}_{3} \mathrm{NH}_{4}, 26.5 \% \mathrm{CaO}\right), 0.35 \mathrm{~kg}$ PG mix 12-14-24 (7\% N-NO 3 , 5\% N-NH $, 14 \% \mathrm{P}_{2} \mathrm{O}_{5}, 24 \% \mathrm{~K}_{2} \mathrm{O}, 2 \% \mathrm{MgO}, 0.03 \% \mathrm{~B}$, $0.15 \% \mathrm{Cu}, 0.09 \% \mathrm{Fe}, 0.16 \% \mathrm{Mn}, 0.2 \% \mathrm{Mo}, 0.04 \% \mathrm{Zn}$ ) and $0.56 \mathrm{~kg}$ Dolokal-5\% (5\% $\mathrm{MgO}, 5.4 \% \mathrm{CaO})$.

From week 3 after sowing until the moment of transplanting, the seedlings in the nursery received twice per week liquid fertilizer which was added to the irrigation water (1.8 EC) resulting in the following concentrations (mmol/L) per element: $1.1 \mathrm{NH}_{4}, 5.11$ $\mathrm{K}, 3 \mathrm{Ca}, 0.87 \mathrm{Mg}, 7.79 \mathrm{NO}_{3}, 1 \mathrm{SO}_{4}$ and $1.5 \mathrm{P}$.

\section{Field Location and Experimental Design}

Field experiments were conducted in 2017 and 2018 at Nergena ( $51^{\circ} 59^{\prime} 40^{\prime \prime} \mathrm{N}, 5^{\circ} 39^{\prime} 24^{\prime \prime}$ E), just north of Wageningen, the Netherlands, on a sandy soil. The experiments were laid out in a split-plot design with three hilling treatments (zero, double, triple) in the main plots and the two genotypes (H03, H04) and two harvest times (intermediate, final) in the sub-plots. There were four replicated blocks.

Seedlings were transplanted by hand in the field on 23 May 2017 and 17 May 2018, 4 - to 5-cm deep in ridges, ensuring that the top of the peat moss substrate was covered with about $1 \mathrm{~cm}$ of soil. Plant distances between rows and plants within rows were $75 \times 20 \mathrm{~cm}$. Gross and net plot dimensions for individual sub-plots were $3.00 \times 1.80 \mathrm{~m}$ and $1.50 \times 1.00 \mathrm{~m}$, respectively, resulting in a net plot area of $1.5 \mathrm{~m}^{2}$ which included 10 plants. Measurements and observations were always made at net plot level.

Hilling was mechanized and done using a Rumptstad speed ridger. Treatment zero was not hilled. Hilling treatment double was hilled twice. The first time, at 23 days after transplanting (DAT) in 2017 and 25 DAT in 2018, was about 2 weeks after the transplanted seedlings showed visible growth in the field. At the moment of the first hilling, the plants had about 10 leaves. The hilling was carried out in such a way that not more than half of the aboveground plant length got covered by soil. The top of the ridge still had a somewhat concave shape after the first hilling treatment. The second hilling was done at 34 DAT in 2017 and 32 DAT in 2018. After the second hilling treatment, the ridge shape was slightly convex on top like the ridges in conventional potato production. The first two hilling applications - as in treatment double - were also applied to hilling treatment triple. In addition, a third hilling was made for this treatment at 42 DAT in 2017 and 40 DAT in 2018. At this third hilling, a maximum 
amount of soil was added to the ridge without losing the common trapezium shape of a conventional potato ridge.

Destructive harvests were made at two moments: (1) an intermediate harvest after or at reaching $100 \%$ ground cover and (2) a final harvest at $>80 \%$ foliage senescence. The intermediate harvest took place at 70 DAT in 2017. In 2018, however, the intermediate harvest was conducted at the moment of $100 \%$ ground cover (53 DAT), based on observations of crop growth and development, as well as analysis of 2017 data (Fig. 2e). In the first year, this was about 2 weeks after the moment of $100 \%$ ground cover. In 2017 final harvest started at 115 DAT when the haulm was removed. At 122 DAT (22 September 2017), tubers were harvested. In 2018, the haulm was harvested at 125 DAT and the tubers at 132 DAT (26 September 2018).

\section{Cultural Practices}

After transplanting, the seedlings immediately received at least $0.1 \mathrm{~L}$ water per plant $\left(0.5 \mathrm{~L} \mathrm{~m}^{-1}\right.$ row) to prevent water-limited conditions for the small root system of the transplant. Water was applied after planting by in-row irrigation using a tractor with a water tank. A boom irrigation system was used later in the growing period to apply additional irrigation when soil moisture content was observed to be low. Weed control was done by hand to prevent unexpected herbicide damage on the experimental hybrid potato genotypes. Further crop management, nutrient and fungicide applications, was done according to Dutch potato farmers' standards.

\section{Observations, Measurements and Calculations}

Daily minimum and maximum temperatures were recorded from the nearby Veenkampen weather station (Fig. 2a). The Veenkampen weather station is situated at $2.9 \mathrm{~km}$ west from the trial fields of this study (www.wur.nl/nl/show/Weather-StationDe-Veenkampen.htm). Applied irrigation was recorded by using two rain gauges in the field (Fig. 2c, d), whereas daily precipitation was recorded from the weather station. Total received water per season (irrigation + precipitation) is shown as accumulated water in Fig. 2 b.

At the intermediate harvests, first the number of plants per net plot was counted; subsequently, the aboveground haulm per net plot was harvested. The haulm fresh biomass was oven-dried for $10 \mathrm{~h}$ at $70{ }^{\circ} \mathrm{C}$ followed by $38 \mathrm{~h}$ at $105{ }^{\circ} \mathrm{C}$, and the aboveground haulm dry weight (DW) per net plot was determined. Secondly, tubers (in 2017) or tubers and stolons (in 2018) were separately harvested. Stolons were, after removal of sand, processed like the aboveground haulm, and DW was recorded.

Tubers were, after removal of sand, grouped in three size classes: $\leq 28 \mathrm{~mm},>28$ and $\leq 40 \mathrm{~mm}$ (further referred to as: $28-40 \mathrm{~mm}$ ) and $>40 \mathrm{~mm}$. Tuber number and tuber fresh weight $(\mathrm{FW})$ were taken per tuber size class per net plot. Thereafter, tubers were cut into pieces of $\leq 1 \mathrm{~cm}$ and oven-dried following the above-mentioned procedure and total tuber DW was recorded per net plot.

At the final harvest, plant number per net plot was counted first, and then, the haulm was removed. Only in 2018 was the haulm oven-dried following the procedure described for the intermediate harvest, and haulm DW was assessed per net plot. After the removal of the haulm, the ridges were characterized; the width at the top of the ridge 


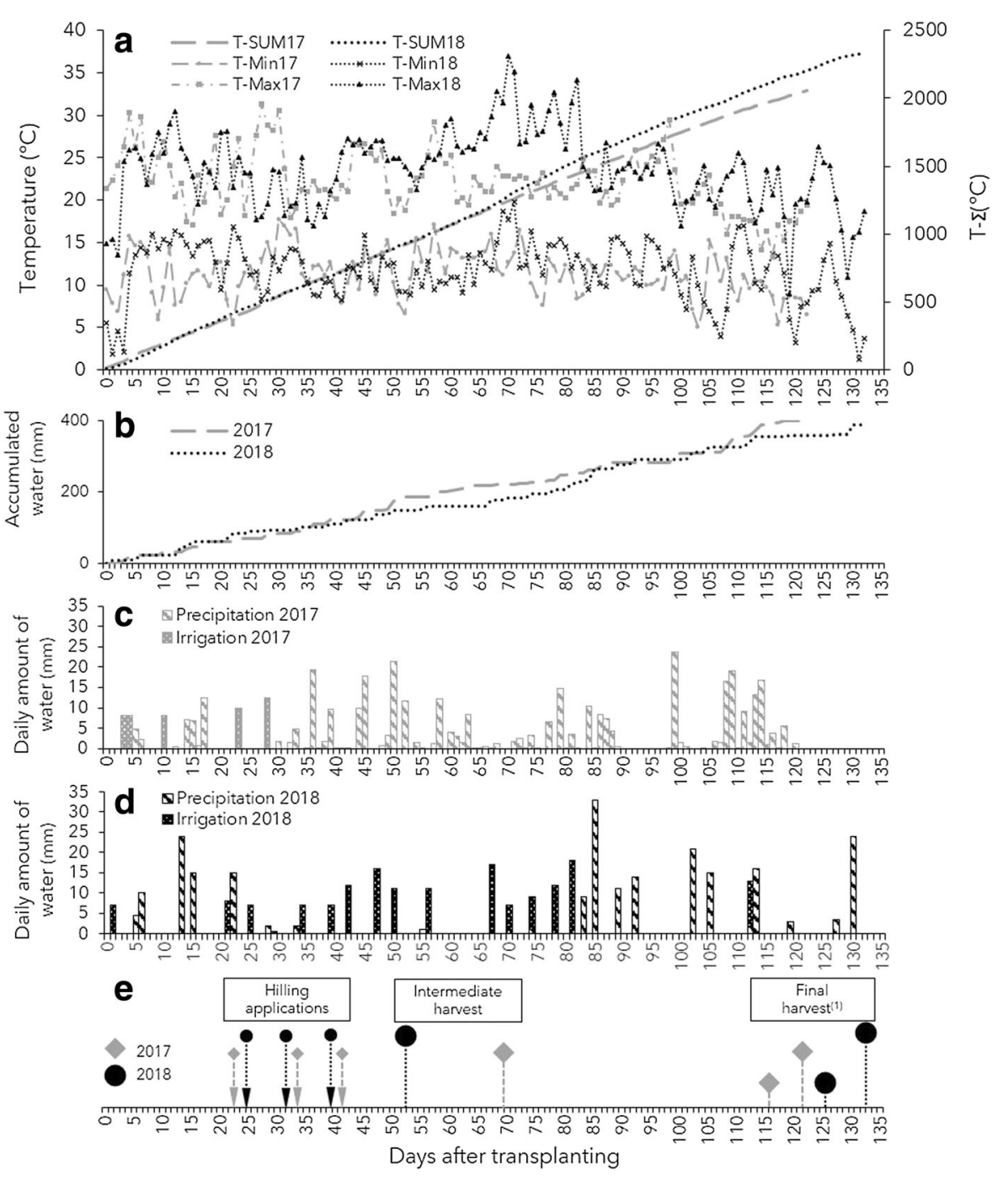

Fig. 2 Temperature, precipitation, applied irrigation and major field events during the field growing period in 2017 and 2018. (a) Minimum (T-Min) and maximum (T-Max) daily temperatures and the temperature sum $(\mathrm{T}-\Sigma)$, Tbase $=0{ }^{\circ} \mathrm{C}$; (b) accumulated amount of water received in the fields; (c) daily amount of water received by precipitation and irrigation in 2017 and (d) in 2018; (e) major field activities. (1) Haulm removal was 7 days prior to tuber harvest

and the height (from top to furrow) were measured at two random positions per hilling treatment per block. One week after removal of the haulm, tubers were harvested per net plot. In 2017, the number and weight of tubers with green discolouration were assessed. The threshold area set for being counted as a discolouration was $\geq$ a 5 Eurocents coin (ø $21.25 \mathrm{~mm}$ ). In 2018, a visual observation revealed that there was less than one discoloured tuber per four plots; therefore, green discoloration was not assessed. In 2017, harvested tubers were sorted and analysed following a similar procedure as for the intermediate harvest; only the smallest tuber size class changed from $\leq 28$ to $>20$ and $\leq 28 \mathrm{~mm}$ (further referred to as: $20-28 \mathrm{~mm}$ ). In 2018 , tuber 
number, size, FW and under water weight (UWW) were assessed using an automated tuber phenotyping line with a 3D camera, as explained by Stockem et al. (2020). Tuber FW and UWW were assessed per net plot. A 3D camera assessed tuber number per net plot and individual tuber size. Based on maximum values for tuber width and height (measured multiple times per tuber), the individual tuber size (square measure) was calculated (Eq. (1)). The individual tuber volume (Eq. (2)) was used to calculate the weight per size class (Eq. (3)). Outcomes were validated in-house (Solynta, personal communication 2020).

Individual tuber size $=\sqrt{2 \times\left(\left(\frac{\text { tuber height }}{2}\right)^{2}+\left(\frac{\text { tuber width }}{2}\right)^{2}\right)}$

Tuber volume $=\frac{1}{6} \times \pi \times$ tuber length $\times$ tuber width $\times$ tuber height

$F W$ tuber size class $a=$ total tuber $F W \times \frac{\sum \text { tuber volume size class } a}{\sum \text { total tuber volume }}$

All obtained weight and tuber number data per net plot were recalculated to data per ha. Tuber dry-matter concentration was calculated from the total tuber FW and DW for both harvest times in 2017 and the intermediate harvest in 2018. For the final harvest in 2018, the tuber dry-matter percentage was derived from the UWW (Stockem et al. 2020) and used to calculate the total DW of the tubers from the total FW. Harvest index (HI) was calculated as tuber DW divided by the DW of tubers plus aboveground haulm, except for final harvest 2017 where the haulm was not harvested and no HI was calculated.

\section{Statistical Analysis}

GenStat 19th edition (VSN International Ltd.) was used for statistical analyses. General analysis of variance was used to test whether the final ridge dimensions differed between the treatments. Analysis of variance for split-plot design was used for all other data. When significant effects of factors were present $(P<0.05)$, means were compared using Fisher's protected LSD test $(\alpha=0.05)$.

\section{Results}

\section{Effects of Hilling Treatments on Ridge Dimensions and Depth of Seedling}

In both years, an increase in the number of hillings resulted in a significant increase in the area of the ridge profile and in the total ridge height from furrow to ridge-top (Table 1). In both years, the mean ridge-profile-area of double was more than twice that of zero. The differences between double and triple were smaller but significant. The top 
Table 1 Final ridge dimensions of the hilling treatments at the final harvest in 2017 (115 days after transplanting) and 2018 (125 DAT)

\begin{tabular}{llccc}
\hline Year & Treatment & Area $\left(\mathrm{cm}^{2}\right)$ & Height $(\mathrm{cm})$ & Top width $(\mathrm{cm})$ \\
\hline 2017 & Zero & $448 \mathrm{a}$ & $11.9 \mathrm{a}$ & $33.0 \mathrm{~b}$ \\
& Double & $928 \mathrm{~b}$ & $18.9 \mathrm{~b}$ & $23.4 \mathrm{a}$ \\
& Triple & $1128 \mathrm{c}$ & $23.0 \mathrm{c}$ & $23.1 \mathrm{a}$ \\
& P value & $<0.001$ & $<0.001$ & $<0.001$ \\
& Zero & $380 \mathrm{a}$ & $9.1 \mathrm{a}$ & $34.3 \mathrm{~b}$ \\
& Double & $779 \mathrm{~b}$ & $15.1 \mathrm{~b}$ & $28.1 \mathrm{a}$ \\
& Triple & $1065 \mathrm{c}$ & $20.8 \mathrm{c}$ & $27.6 \mathrm{a}$ \\
& P value & $<0.001$ & $<0.001$ & $<0.001$ \\
\hline
\end{tabular}

Different letters indicate a significant difference based on Fisher's protected LSD-test $(\alpha=0.05)$

Ridge height was measured from top to furrow bottom

width of the ridges was wider under the zero treatment than under the double and triple treatments (Table 1).

Figure 3 visualizes the final ridge dimensions of treatments zero, double and triple at the final harvest relative to their initial ridge at time of transplanting. The initial ridges in 2017 and 2018 differed in shape and height. In 2017, the initial ridge had a larger total volume, steeper outer slopes and a lower top compared with 2018. The improved initial ridge of 2018 had a pronounced V-shaped planting furrow in the ridge-centre, which allowed deeper transplantation of the seedling relative to the ridge top in the initial ridge as well as closer to the ground level than in 2017.

\section{Intermediate Harvest}

An intermediate destructive harvest took place at 70 days after transplanting (DAT) in 2017 and at 53 DAT in 2018, which was 20 and 0 days after canopy closure, respectively. All transplanted plants had developed into tuber bearing plants. In both

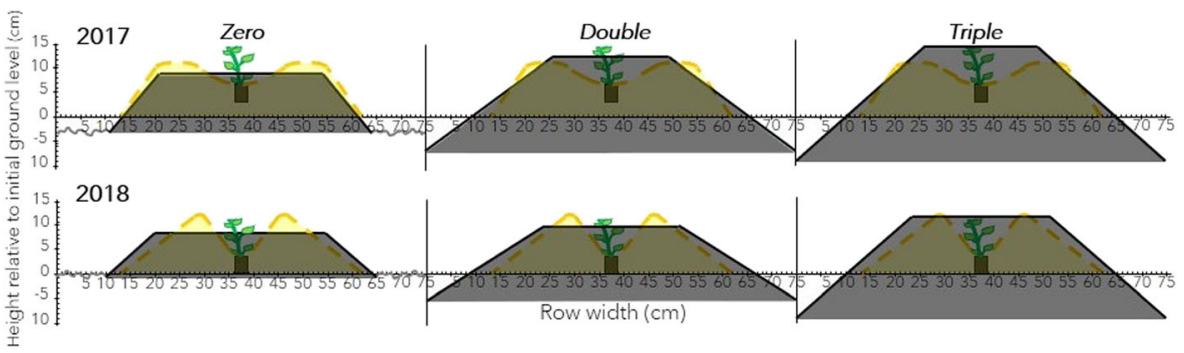

Fig. 3 Schematic overview of the initial ridges at planting (light coloured shape, dashed line), position of the transplanted seedling in the ridge after planting (see also Figure. S1 in Supplementary material), and the final ridges of the different hilling treatments (zero, double and triple) at the final harvest after removal of the haulm (dark shape, black line) in 2017 and 2018. Plant and ridge height are indicated on the vertical axis, $0=$ field ground level at transplanting, squiggly lines next to the zero-ridges indicate their ground level between ridges at the final harvest 
years, no significant genotype $\times$ hilling treatment interactions were found. Only in 2018 did the hilling treatment significantly affect some of the crop parameters.

In 2017, tuber fresh weight (FW) and tuber number at intermediate harvest did not differ between the hilling treatments in any of the tuber size classes or in total number or weight (Fig. 4a, c; Table S1), although the number of tubers, especially the smallest tubers, tended to increase with increased number of hilling applications. In 2018 at 53 DAT, compared with no hilling (zero), treatments that were subjected to double and triple hilling applications had a higher tuber FW and a higher number of tubers as well as total tubers with tubers $\leq 28 \mathrm{~mm}$ (Fig. $4 \mathrm{~b}, \mathrm{~d}$ ). Additionally, in 2018, total tuber dry weight and the harvest index (HI) were higher in hilling treatments double and triple than in zero hilling at the intermediate harvest (Table 2).

In 2017, genotype H03 had a higher total tuber FW at the intermediate harvest than genotype H04 (Table 2), whereas the tuber DW per ha did not differ significantly between genotypes (Table S1). Tuber dry-matter percentage (DM\%) was significantly higher in H04 than H03 (Table 2). In both years, the number of tubers and the weight of several non-tuber plant parts were higher in genotype H04 than in genotype H03 in the intermediate harvest (Table 2).
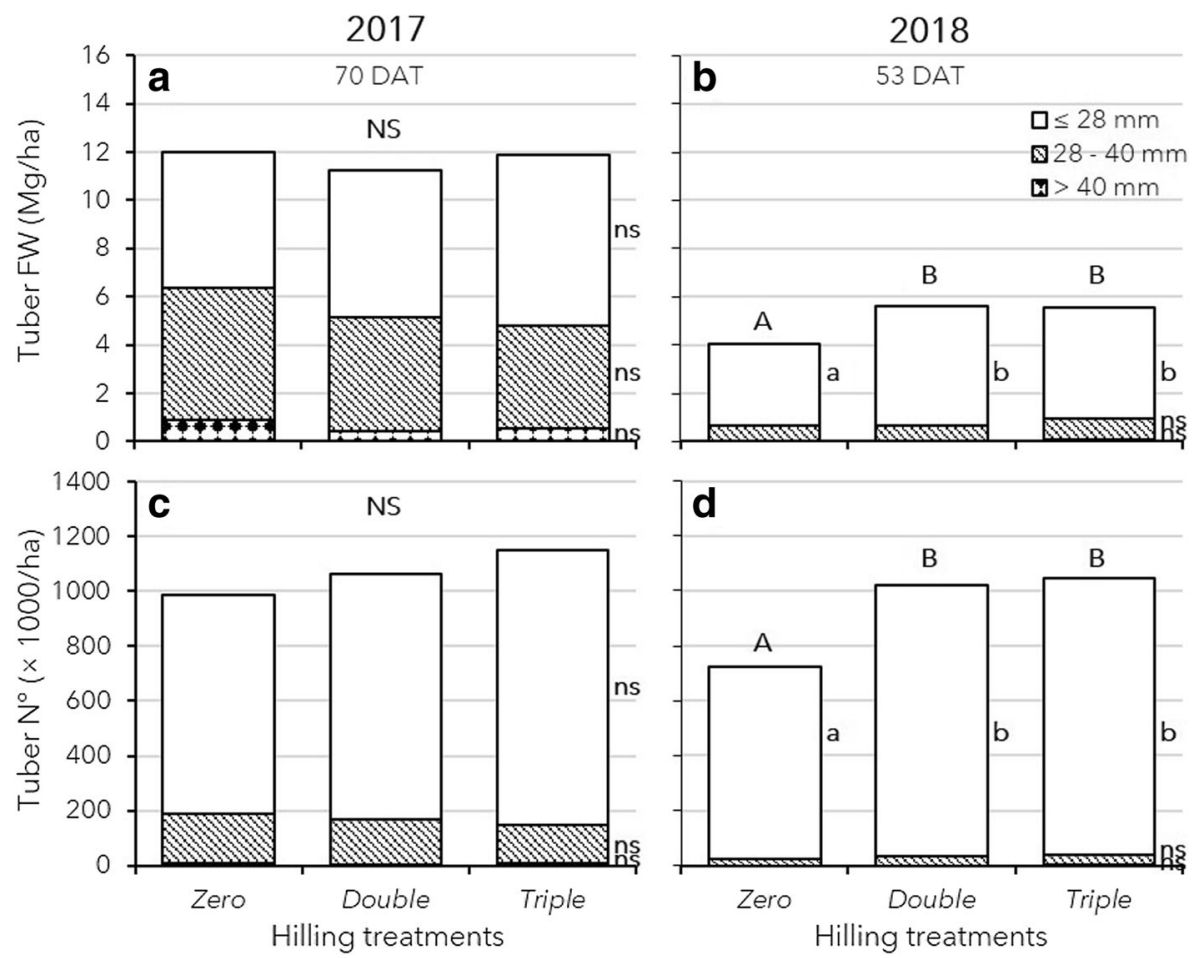

Fig. 4 Effects of hilling on tubers at the intermediate harvest in 2017 (a, c), 70 days after transplanting, and 2018 (b, d), 53 DAT. Tuber fresh yields (FW) are shown on top (a, b), tuber numbers at the bottom $(\mathbf{c}, \mathbf{d})$. Different letters indicate a significant difference based on Fisher's protected LSD-test $(\alpha=0.05)$. Capital letters on top of the bars are for the effects of hilling treatments on the total tubers, lower case letters far right are for the individual tuber size classes. Not significant $(P \geq 0.05)$ is indicated for total tubers by NS and for the individual size classes by ns 


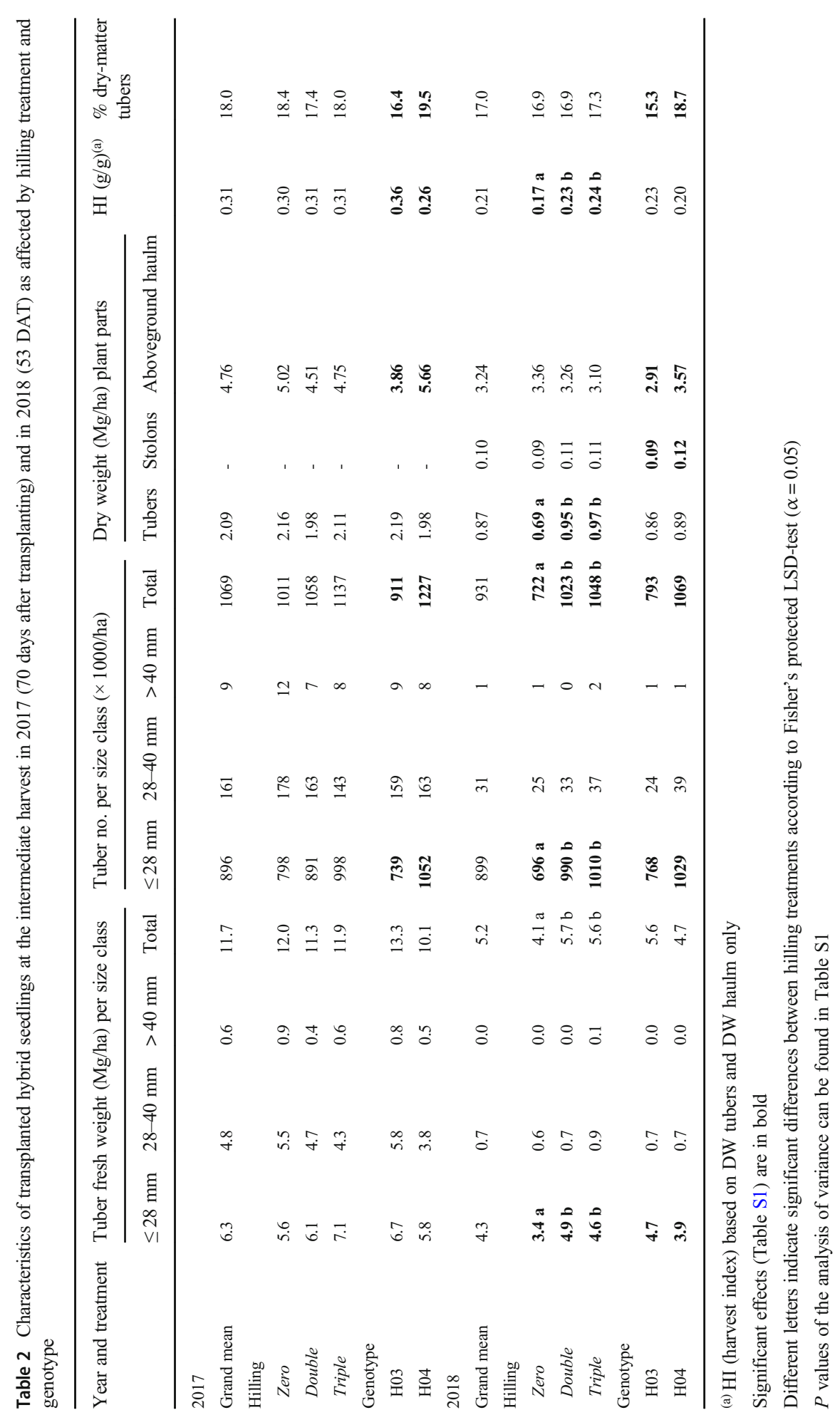




\section{Final Harvest-Effects of Hilling}

The final harvest was done in 2017 at 122 DAT and in 2018 at 132 DAT. All transplanted seedlings had developed into fully matured plants at the final harvest. In both years, no significant interactions were found between genotype and hilling treatment (Table S1). The hilling treatment affected some of the crop parameters only significantly in 2017 (Table S1).

Total tuber yield was not affected by the hilling treatment in both years (Fig. 5a, b; Table S1). However, in 2017, hilling treatment zero resulted in a significantly higher yield in tuber size class $>40 \mathrm{~mm}$ than hilling treatment triple. The treatment double had an intermediate yield and did not significantly differ from the other hilling treatments. The opposite effect was observed for the smallest tuber size class, 20-28 mm, where zero hilling resulted in a significantly lower tuber FW than triple and double. In 2018, yield per size class did not differ significantly between hilling treatments, but a similar trend was found as in 2017 where hilling treatment zero, compared with double and triple, had a higher tuber yield in size class $>40 \mathrm{~mm}$ and a lower yield in class 20 $28 \mathrm{~mm}$.
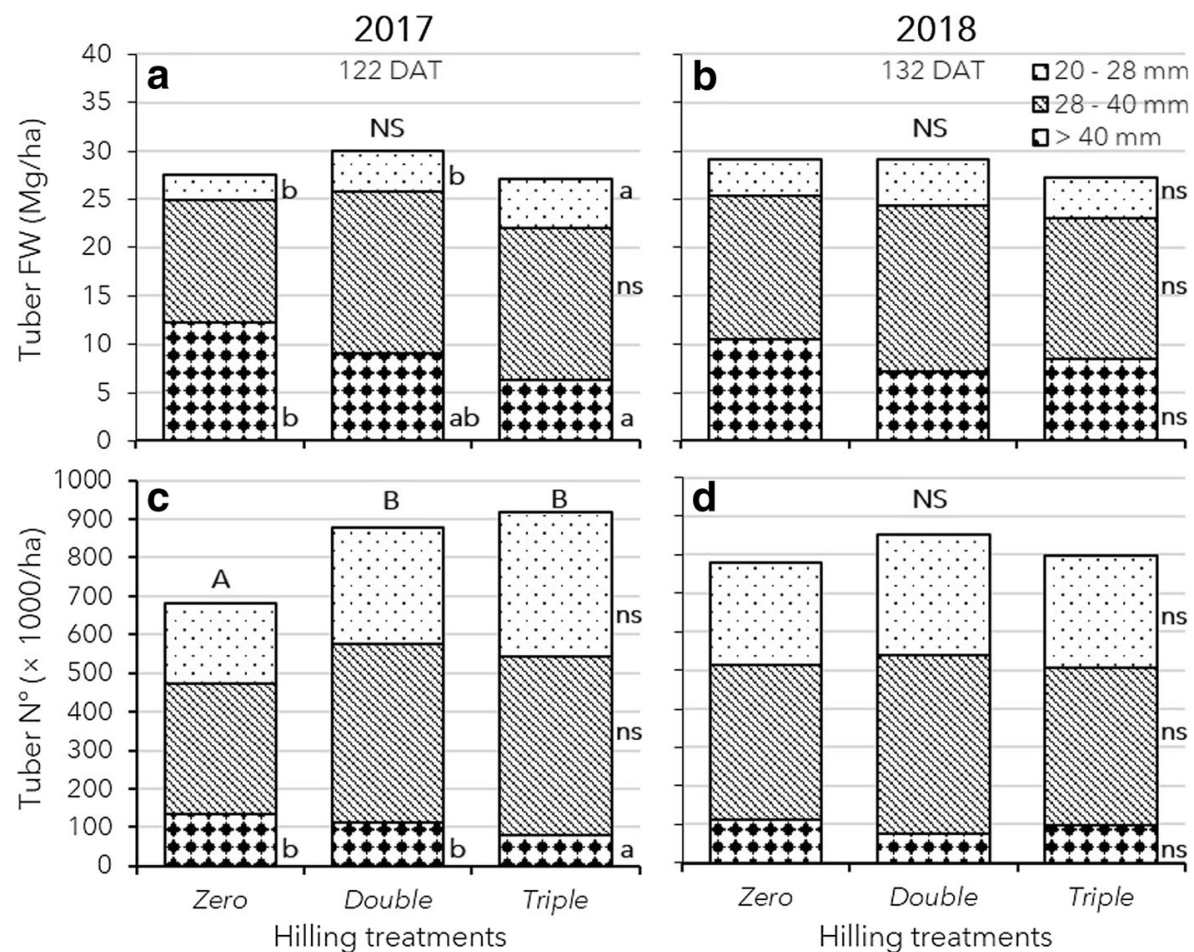

Fig. 5 Effects of hilling on tuber yield and number at the final harvest in 2017 (a, c), 122 days after transplanting, and 2018 (b, d), 132 DAT. Tuber fresh yield (FW) is shown on top (a, b), tuber numbers at the bottom $(\mathbf{c}, \mathbf{d})$. Per hilling treatment, tubers were divided into three size classes. Different letters indicate a significant difference based on Fisher's protected LSD-test $(\alpha=0.05)$; capital letters on top of the bars for the effect of hilling treatments on the total tuber number, lower case letters far right are for the individual tuber size classes. Not significant $(P \geq 0.05)$ is indicated for total tubers by NS and for the size classes by ns 
In 2017, significantly more tubers were produced under hilling treatments double and triple than under zero (Fig. 5c), but this was not reflected in significantly more tubers for these treatments in any of the size classes. There even were significantly more tubers in the size class $>40 \mathrm{~mm}$ produced under the zero and double treatments compared with the triple treatment. In 2018, hilling treatments did not result in significant differences in tuber numbers (Fig. 5d), but, comparable with 2017, most tubers in size class $>40 \mathrm{~mm}$ were produced under treatment zero.

In line with the total number of tubers per ha, in 2017, the total number of tubers per plant increased following the hilling treatments; plants produced 10.2, 13.2 and 13.8 tubers per plant under the respective hilling treatments zero, double and triple. In 2018, the average total number of tubers per plant was 12.1 and did not differ between hilling treatments (data not shown).

The hilling treatments did not affect total tuber DW or tuber DM\% at the final harvest in both years (Table S1). Green discoloured tubers were only assessed in 2017 because greening was negligible in 2018. In 2017, double and triple hilling decreased the total FW and number of green tubers compared to zero hilling (Table 3); about 5, 2 and $1 \%$ of the total FW under the respective treatments zero, double and triple were green discoloured (data not shown).

\section{Final Harvest-Obtained Yields and Genotypic Effects}

The average total tuber yield was $28.2 \mathrm{Mg} / \mathrm{ha}$ in 2017 and $28.5 \mathrm{Mg} / \mathrm{ha}$ in 2018 . Genotype H03 produced $30.3 \mathrm{Mg} / \mathrm{ha}$ in 2017 and $32.4 \mathrm{Mg} / \mathrm{ha}$ in 2018 (Table 3). These total tuber yields were significantly higher than those of H04 in 2017 and 2018 , which were 26.2 and $24.7 \mathrm{Mg}$ /ha in the respective years. In 2018, this was largely caused by a higher weight of tubers in the size class $>40 \mathrm{~mm}$ in genotype H03 than in genotype H04. In 2017, the difference between genotypes in weight of tubers $>40 \mathrm{~mm}$ was not significant, but the same trend was visible as in 2018 (Table 3).

Genotype H03 produced significantly fewer tubers than genotype H04 in both years. In 2018 this was clearly caused by genotype H03 having significantly fewer tubers in the smallest size class, 20-28 mm, than genotype H04. In 2017, the same trend occurred, but differences were not significant. In 2018, genotype H03 produced significantly more large-sized tubers $(>40 \mathrm{~mm})$ than $\mathrm{H} 04$, which explains the higher yield of $\mathrm{H} 03$ compared with $\mathrm{H} 04$, both for tubers $>40 \mathrm{~mm}$ and total tubers (Table 3 ). These tuber numbers corresponded with similar differences in tuber number per plant. H03 bore in total 11.1 and 11.0 tubers $(>20 \mathrm{~mm}$ ) per plant in 2017 and 2018, respectively, which was a lower number than H04, bearing 13.7 and 13.2 tubers $>20 \mathrm{~mm}$ per plant in the respective years (data not shown). Mean total numbers of tubers $>20 \mathrm{~mm}$ per plant were 12.4 and 12.1, respectively, in 2017 and 2018 and 8.0 and 7.8 tubers per plant which were > $28 \mathrm{~mm}$ (data not shown).

In both years, the tuber DM\% of genotype H04 was higher $(22.5 \%$ and $22.0 \%)$ than the DM\% of genotype H03 (18.2\% and 18.0\%). Because the total tuber DW did not differ between genotypes in both years, the higher total FW of tubers in genotype $\mathrm{H} 03$ compared with $\mathrm{H} 04$ can be explained by a higher water content of the tubers in $\mathrm{H} 03$. 


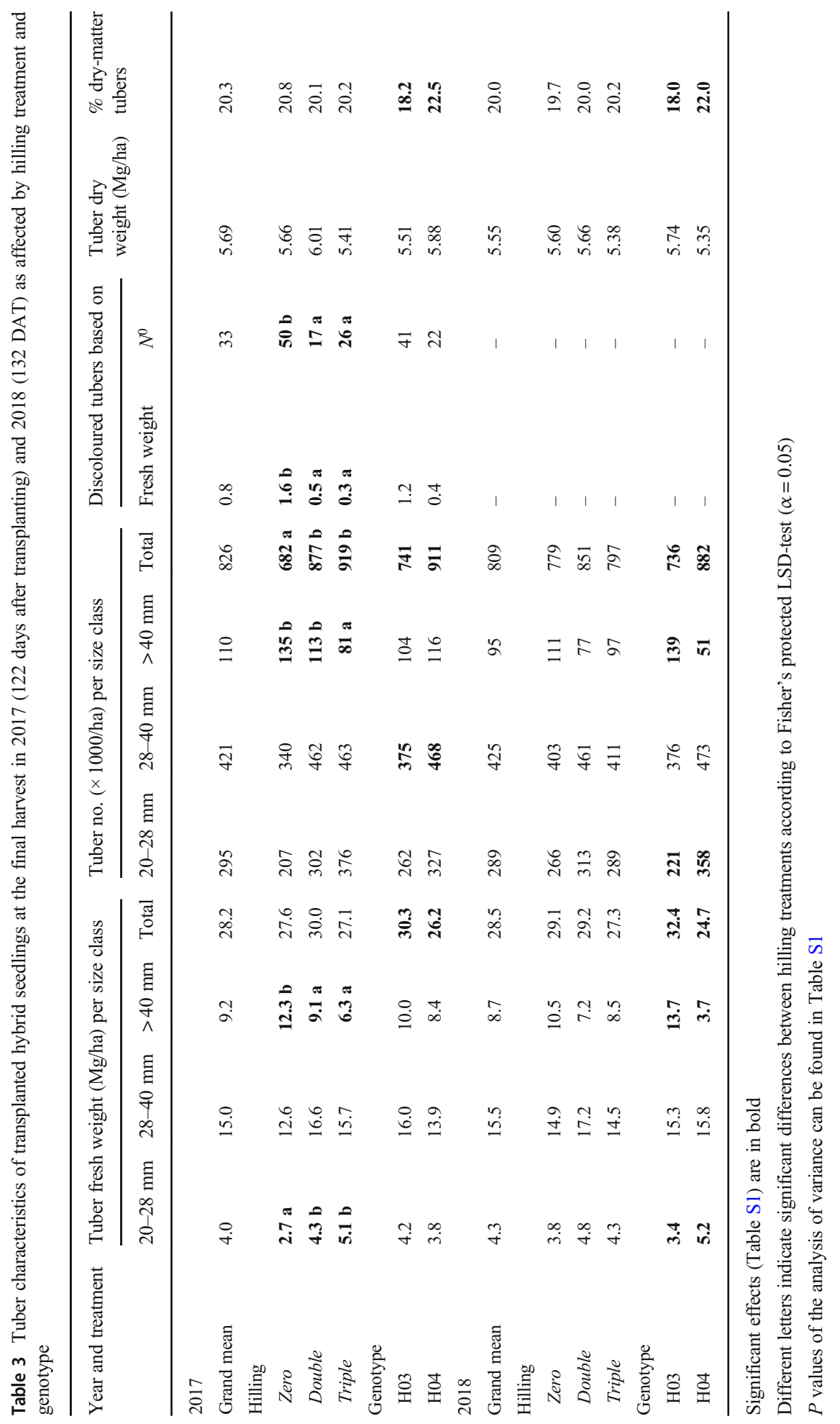




\section{Discussion}

The objectives of this study were to analyse possible effects of hilling on tuber fresh weight, tuber number, tuber size distribution, tuber dry-matter percentage and potential tuber greening, as well as to determine the yield of transplanted hybrid seedlings under normal Dutch potato growing practices. Additionally, we will evaluate in this discussion the method used for planting the hybrid potato seedlings and elaborate for the first time on how the use of transplanted hybrid seedlings might affect the Dutch seed tuber value chain.

\section{Transplanting of Hybrid Seedlings in a Ridge System}

In both years, it was possible to create ridges that significantly differed in height and ridge profile area between treatments. The initial profile at planting in 2017 was slightly different from the one in 2018. In 2018, an improved initial ridge was created, with a pronounced $\mathrm{V}$-shaped planting furrow in the ridge to protect the vulnerable transplanted seedlings against strong wind (Fig. 3). The V-shaped inner ridge of 2018 was deeper than in 2017 , and due to its V-shape, the seedlings were planted deeper in 2018 compared with 2017 (respectively, 3.5 and $1.5 \mathrm{~cm}$ from ridge top to root-shoot junction, Fig. 3). Due to the different ridge profiles, seedlings were also planted closer to the ridge base in 2018, compared with 2017. The different, improved ridge profile in 2018 was prone to erosion at the inner side, whereby the tops collapsed gradually after planting, thereby gradually covering the lower parts of the transplanted seedling. This resulted in a 'natural earthing-up' of the zero treatment.

\section{Effects of Hilling on Plant Performance}

At the final harvest, the hilling treatment of the transplanted hybrids did not affect the total fresh tuber yield or tuber dry weight in either year. Even though only significantly proven in one of the 2 years, this study suggests that transplanted hybrid potato plants produce more tubers under hilled conditions and that hilling changes the tuber size distribution to a certain degree; this was significant in 2017 and visible as a trend in 2018. Practising zero hilling resulted in higher fresh weight and/or number of tubers in the largest size class $(>40 \mathrm{~mm})$, and lower tuber weight or number in the smallest size class $(>20-28 \mathrm{~mm})$ than double or triple hilling. The lack of effect on total tuber fresh or dry weights shows that the production capacity of the crop was not influenced by hilling.

The higher number of tubers in the hilled treatments, compared with zero, might be related to an increased initiation of stolons, which often results in an increased tuber initiation and tuber number. In other studies, where hilling was studied in tetraploid TPS materials or cuttings, it was explained that hilling, by covering aboveground nodes with soil, creates more space on the below ground stem for possible stolon positions (Wiersema 1984; Escobar and VanderZaag 1988). The improved initial ridge shape in 2018, which resulted in a 'natural earthing-up', would gradually have led to more covered nodes able to initiate stolons and tubers and an absence of significant differences between hilling treatments. 
When more tubers are initiated per plant, these tubers will have less resources available per individual tuber, which limits the bulking of individual tubers and leads to the presence of many small sized tubers (cf. Ewing and Struik 1992; Struik and Wiersema 1999).

Besides, the application of the hilling treatments (two times for double, three times for triple) did always cover the lower leaves of the young transplanted seedlings, and slightly damaged the immature canopies (personal observations, not measured or shown). This disturbance in the haulm might have come with a cost to the amount of assimilates the plants could produce by its photosynthesis (Taylor 1953; Boyd et al. 2002). Plants in the zero treatment did not receive hilling applications and had therefore an undisturbed (canopy) development. It might be assumed that the process of tuber bulking happened also undisturbed in the zero treatment and started around canopy closure (Burt 1964; Kouwenhoven 1970; Struik et al. 1990). The tubers under the zero treatment therefore had better opportunities to become stronger sinks than their (disturbed) counter parts under hilled treatments, and thus tubers under zero hilling could grow bigger (Wiersema 1984; Struik et al. 1990; Ewing and Struik 1992; Struik and Wiersema 1999; Kloosterman and Bachem 2014; Wohleb et al. 2014).

\section{Yield Levels of Hybrid Potato Crops from Transplanted Seedlings}

Average tuber yield levels across genotypes obtained in the present experiments with transplanted hybrid seedlings were $28.2 \mathrm{Mg} /$ ha total yield in 2017 and $28.5 \mathrm{Mg} / \mathrm{ha}$ in 2018. The total yields were 30.3 and $32.4 \mathrm{Mg} /$ ha for genotype H03 and 26.2 and $24.7 \mathrm{Mg} /$ ha for genotype H04 in the respective years. This is the first information on yield of transplanted hybrid diploid potato seedlings under mechanized temperate cropping conditions. Achieved experimental yields are a little lower than the average (2010-2019) Dutch seed tuber yield of $36 \mathrm{Mg} / \mathrm{ha}$ and much lower than the average (2010-2019) ware potato yield in the Netherlands of $49 \mathrm{Mg} /$ ha (CBS 2020). Achieved yields of the experimental hybrid diploid seedlings in this study are in line with those reported in studies of single stem tetraploid potato planting materials such as in vitro plantlets and minitubers. Field transplanted potato plantlets, produced in a greenhouse nursery and derived from in vitro multiplication, can generate experimental yields, depending on treatment, year and genotype, between 14 and $35 \mathrm{Mg} / \mathrm{ha}$ and $25 \mathrm{Mg} / \mathrm{ha}$ on average at $70 \mathrm{DAT}$ (Lommen 2015) or between 25 and $56 \mathrm{Mg} / \mathrm{ha}$ at $84 \mathrm{DAT}$ (Tadesse et al. 2001b). Studies with plants grown from minitubers reported yields between 6 and $39 \mathrm{Mg} /$ ha depending on minituber size and density (Lommen and Struik 1994; Struik and Wiersema 1999). The higher yields from minitubers were achieved at high planting densities and/or with the larger-sized minitubers, but also in shorter field growing periods than the present hybrid seedlings.

The tubers produced in the present experiments can serve as seedling tubers for producing a seed tuber crop in the second season and ware crop in the third season (Fig. 1) or can be planted for directly producing a ware crop in the second season as done by Stockem et al. (2020). Producing ware tubers from hybrid TPS in only two or three seasons decrease considerably the number of generations compared with the conventional seed tuber multiplication system, which is beneficial for the crop's health (Struik and Wiersema 1999; Lammerts van Bueren and Van Loon 2011; TiemensHulscher et al. 2013; Almekinders et al. 2014; Thomas-Sharma et al. 2016). 


\section{Possible Implications for Dutch Seed Tuber Production}

Due to low multiplication factors of potato plants in the conventional clonal system, seed tubers are multiplied for 5 to 8 years before they are planted to produce ware (Struik and Wiersema 1999; Tiemens-Hulscher et al. 2013). Storage and transport of seed tubers between every growing period are costly and precise undertakings (Booth and Burton 1983; Beukema and Van der Zaag 1990; Cunnington 2008; Haverkort and Hillier 2011). Decreasing the number of field multiplications can reduce labour and energy costs (Haverkort and Hillier 2011) and acreage, and benefits seed tuber health (Struik and Wiersema 1999; Thomas-Sharma et al. 2016). Starting with TPS, which has multiplication rates of $>1000$ (Almekinders 1995) compared with 10 for clonal multiplication (Struik and Wiersema 1999), allows fewer field multiplications before having a sufficient amount of starting material to grow a ware crop.

To assess the potential of transplanted hybrid seedlings on the potato cultivation chain, the Dutch conventional system will be used as a basis to calculate the potential impact of using transplanted hybrid seedlings. This study showed that a final number of 8.0 and 7.8 tubers $>28 \mathrm{~mm}$ per plant was produced or 531,000 tubers per ha in 2017 and 519,000 tubers per ha in 2018 at a planting density of 66,667 transplanted seedlings per ha (calculated from Table 3). Using the average of the two experimental years, transplanted hybrid seedlings produced 525,000 seedling tubers per hectare. Either almost 12 ha of ware crop could be grown using the seedling tubers, or almost 8 ha of seed tubers, using as rules of thumb, the Dutch potato farmers standard planting densities: 44,444 seed tubers are planted for ware production and 66,667 tubers seed potato production.

To plant 1 ha of hybrid transplants for seedling tuber production at the spacing used in the present experiments (66,667 transplants per ha), $120 \mathrm{~m}^{2}$ net greenhouse area and hardening area are needed for transplant production, using similar nursery trays as in this study and assuming a hypothetical $90 \%$ rate of usable hybrid seedlings at the end of a 5-week greenhouse nursery period. Following the above-mentioned assumptions, 78 ha of greenhouse nursery is needed to grow the current Dutch area of 77,557 ha in 2019 (CBS 2020) under ware potato production directly from transplanted hybrid seedlings. In 2018, 470 ha of greenhouse area in the Netherlands was dedicated to produce various other vegetable seedlings for transplanting (CBS 2020). Most of these vegetable seedlings were raised during the same period as the hybrid potato seedlings are transplanted into the field (De Visser 1989; Vermeulen 2012; Spruijt and Van der Voort 2015). It might be unrealistic to add 78 ha of specialized greenhouse area for hybrid potato seedling to the current 470 ha for other vegetables. Following Struik and Wiersema's (1999) seed crop to ware crop acreage ratio of 1:10, every added season of seed tuber multiplication reduces the necessary greenhouse nursery area by a factor 10 . With only around 7.8 ha of greenhouse nursery dedicated to hybrid potato seedling production one could in theory produce ware from hybrid TPS in only 2 seasons (Fig. 1) instead of 5 to 8 years in the current Dutch potato value chain.

Of the total Dutch seed tuber production, 70\% is exported (Agrimatie 2020), which equals 30,422 ha in 2018 (CBS 2020). First-generation seedling tubers grown from transplanted hybrid seedlings could replace the currently exported seed tubers. To plant the current area under seed tuber export cultivation with hybrid seedlings, $2.03 \times 10^{9}$ seedlings need to be produced on 361 ha of greenhouse nursery and hardening area. When one or two seasons of clonal multiplication (respectively, Season 2 and 3 in 
Fig. 1) are added, only 36.1 or 3.6 ha of greenhouse nursery would be needed to grow the whole Dutch seed tuber export, starting from transplanted hybrid seedings and exporting, respectively, second- or third-generation seed tubers.

Following the above-mentioned assumptions, 11.4 ha of net greenhouse nursery and hardening area is needed to grow Dutch ware potato production and seed tuber export production with transplanted hybrid seedlings. Dutch ware potatoes will be grown from first-generation seedling tubers and the seed tuber export multiplies until the third-generation seed tubers before shipping their product to foreign countries.

\section{Further Studies}

The current study only showed minor effects of hilling on the yield and yield components of transplanted experimental hybrid seedlings. However, when improved hybrid cultivars are developed, cultivar-specific responses to hilling and transplanting depth will be important aspects to study (cf. Kouwenhoven 1970). Meanwhile, studies on the potential of novel systems to cultivate hybrid potato should focus on other crucial aspects of the agronomy of such systems, including transplanting time, harvesting date and population density of transplants.

In the present experiments, transplanting was done in the second half of May (23 May in 2017 and 17 May in 2018) to limit risks of frost or cold damage. It is unknown if earlier transplanting of hybrid seedlings, and thus lengthening the duration of the growing period at the start of the season, could increase average tuber size and total yield. On the other hand, cold tolerance of transplanted (hybrid) seedlings has not been studied and reported. It might be worthwhile to study if a longer cropping cycle is beneficial for total tuber production.

Planting density of a standard seed tuber crop was used in this study due to the single stem habit of potato plants grown from TPS. It is not yet known if different planting densities under Dutch conditions will have an influence on total tuber yield and tuber size distribution.

\section{Conclusions}

Hilling did not increase yield compared with zero hilling, but can increase tuber number, and tends to change tuber size distributions towards smaller tubers. Zero hilling tended to result in more large-sized tubers and a higher yield in the largest size class than hilled treatments. When hybrid seedlings are transplanted in a Vshaped ridge, hilling is not needed to prevent tuber greening.

Transplanting hybrid seedlings from a greenhouse nursery into the field was shown to be a feasible cultivation pathway for producing seedling tubers under Dutch conditions. Total yields of $32 \mathrm{Mg} /$ ha could be reached using experimental genotypes. This is very close to yield levels of Dutch seed potato production. Under experimental conditions, plant survival after transplanting was $100 \%$, and on average 12.3 tubers were produced per plant, of which 7.9 tubers were $>28 \mathrm{~mm}$. Using this multiplication factor and the present nursery conditions, it was calculated that 7.8 ha of net greenhouse and hardening area will be needed to plant the current 77,557 ha of Dutch ware production with first-generation seedling tubers. 
Authors' Contributions LCMvD designed and carried out the field trials and collected the data. Data analyses were done by LCMvD and OCK. All authors contributed to data interpretation. The manuscript was drafted by LCMvD and revised based on the input of all authors.

Funding This study was part of the Potarei project funded by the Responsible Research and Innovation programme of the Netherlands Organisation for Scientific Research. (NWO; 313-99-301). Additional funding came from Solynta, Kramp Group and Ubbo Emmius Fund.

\section{Compliance with Ethical Standards}

Conflict of Interest The authors declare that they have no conflict of interests.

Ethics Approval Not applicable.

Consent to Participate Not applicable.

Consent for Publication Yes

Availability of Data and Material Yes

Code Availability Not applicable.

Open Access This article is licensed under a Creative Commons Attribution 4.0 International License, which permits use, sharing, adaptation, distribution and reproduction in any medium or format, as long as you give appropriate credit to the original author(s) and the source, provide a link to the Creative Commons licence, and indicate if changes were made. The images or other third party material in this article are included in the article's Creative Commons licence, unless indicated otherwise in a credit line to the material. If material is not included in the article's Creative Commons licence and your intended use is not permitted by statutory regulation or exceeds the permitted use, you will need to obtain permission directly from the copyright holder. To view a copy of this licence, visit http://creativecommons.org/licenses/by/4.0/.

\section{References}

Agrimatie (2020) De aardappelketen. Wageningen Economic Research, The Hague, Netherlands https:// wwwagrimatienl/ThemaResultaataspx?subpubID=2232\&themaID=3577\&indicatorID=3591\&sectorID= 2417. Accessed 18 March 2020

Almekinders CJM (1995) On flowering and botanical seed production in potato (Solanum tuberosum L.). Dissertatoin, Wageningen University

Almekinders CJM, Chilver AS, Renia HM (1996) Current status of the tps technology in the world. Potato Res 39(2):289-303. https://doi.org/10.1007/BF02360921

Almekinders CJM, Chujoy E, Thiele G (2010) The use of true potato seed as pro-poor technology: the efforts of an international agricultural research institute to innovating potato production. Potato Res 52(4):275275. https://doi.org/10.1007/s11540-009-9142-5

Almekinders CJM, Mertens L, Van Loon JP, Lammerts van Bueren ET (2014) Potato breeding in the Netherlands: a successful participatory model with collaboration between farmers and commercial breeders. Food Sec 6(4):515-524. https://doi.org/10.1007/s12571-014-0369-x

Bachem CWB, Eck HJ, de Vries ME (2019) Understanding genetic load in potato for hybrid diploid breeding. Mol Plant 12(7):896-898. https://doi.org/10.1016/j.molp.2019.05.015

Bethke PC, Halterman DA, Jansky SH (2019) Potato germplasm enhancement enters the genomics era. Agronomy 9(10):575-575. https://doi.org/10.3390/agronomy9100575

Beukema HP, van der Zaag DE (1990) Introduction to potato production. Pudoc, Wageningen 
Booth RH, Burton WG (1983) Future needs in potato post-harvest technology in developing countries. Agric Ecosyst Environ 9(3):269-280. https://doi.org/10.1016/0167-8809(83)90101-9

Boyd NS, Gordon R, Martin RC (2002) Relationship between leaf area index and ground cover in potato under different management conditions. Potato Res 45:117-129. https://doi.org/10.1007/BF02736107

Burrows WC (1963) Characterization of soil temperature distribution from various tillage-induced microreliefs. Soil Sci Soc Am J 27:350-353. https://doi.org/10.2136/sssaj1963.03615995002700030038x

Burt RL (1964) Influence of short periods of low temperature on tuber initiation in the potato. Eur Potato J 7 : 197-208. https://doi.org/10.1007/BF02368251

Carling DE, Walworth JL (1990) The effect of hilling on yield and quality of potatoes. University of Alaska Fairbanks, School of Agriculture and Land Resources Management. http://hdl.handle.net/11122/2250

CBS (2020) CBS StatLine. Centraal Bureau voor de Statistiek, Nederland. https:/opendatacbsnl/statline/. Accessed 18 March 2020

Cunnington AC (2008) Developments in potato storage in Great Britain. Potato Res 51:403-410. https://doi. org/10.1007/s11540-008-9113-2

De Visser AJ (1989) New vegetable crops in the Netherlands for protected cultivation: conditions for selection. Acta Hortic 242:65-70. https://doi.org/10.17660/ActaHortic.1989.242.7

De Vries M, Ter Maat M, Lindhout P (2016) The potential of hybrid potato for East-Africa. Open Agric 1: 151-156. https://doi.org/10.1515/opag-2016-0020

Edelenbosch R, Munnichs G (2020) De aardappel heeft de toekomst - Drie scenario's over de hybride aardappel en de wereldvoedselvoorziening. Rathenau Instituut, Den Haag https://www.rathenau.nl/nl/ maakbare-levens/de-aardappel-heeft-de-toekomst

Engels C, Schwenkel J, Bedewy R, Sattelmacher B (1995) Effect of the developmental stage of potato seedlings on recovery after transplanting to the field and on tuber yield. J Agric Sci 124(2):213-218. https://doi.org/10.1017/S0021859600072889

Engels C, Schwenkel J, Sattelmacher B, El Bedewy R (1994) Potato production from true potato seed (tps) in Egypt: effect of the growing season on seedling development, recovery from transplanting and yield. Potato Res 37(3):233-243. https://doi.org/10.1007/BF02360515

Escobar V, VanderZaag P (1988) Field performance of potato (Solanum spp.) cuttings in the warm tropics: influence of planting system, hilling, density and pruning. Am J Potato Res 65(1):1-10. https://doi.org/10. 1007/BF02855308

Ewing EE, Struik PC (1992) Tuber formation in potato: induction, initiation, and growth. In: Janick J (ed) Horticultural Reviews, vol 14. Wiley, New York, pp 89-198. https://doi.org/10.1002/9780470650523. ch3

Frantz JM, Welbaum GE, Shen Z, Morse R (1998) Comparison of cabbage seedling growth in four transplant production systems. HortSci 33(6):976-979. https://doi.org/10.21273/HORTSCI.33.6.976

Haverkort AJ, Hillier JG (2011) Cool farm tool - potato: model description and performance of four production systems. Potato Res 54:355-369. https://doi.org/10.1007/s11540-011-9194-1

Jansky SH, Charkowski AO, Douches DS, Gusmini G, Richael C, Bethke PC, Spooner DM, Novy RG, De Jong H, De Jong WS, Bamberg JB, Tomphson AL, Bizimungu B, Holm DG, Brown CR, Haynes KG, Sathuvalli VR, Veilleux RE, Miller C, Bradeen JM, Jiang J (2016) Reinventing potato as a diploid inbred line based crop. Crop Sci 56(4):1412-1422. https://doi.org/10.2135/cropsci2015.12.0740

Kerbiriou PJ, Stomph TJ, Lammerts van Bueren ET, Struik PC (2013) Influence of transplant size on the above- and below-ground performance of four contrasting field-grown lettuce cultivars. Front Plant Sci 4(379):1-16. https://doi.org/10.3389/fpls.2013.00379

Kloosterman B, Bachem C (2014) Tuber development. In: Navarre R, Pavek MJ (eds) The potato: botany, production and uses. CABI, Boston, pp 45-63

Kouwenhoven JK (1970) Yield, grading and distribution of potatoes in ridges in relation to planting depth and ridge size. Potato Res 13(1):59-77. https://doi.org/10.1007/BF02355893

Kouwenhoven JK, Perdok UD, Jonkheer EC, Sikkema PK, Wieringa A (2003) Soil ridge geometry for green control in French fry potato production on loamy clay soils in the Netherlands. Soil Tillage Res 74(2): 125-141. https://doi.org/10.1016/S0167-1987(03)00149-1

Lammerts van Bueren ET, van Loon JP (2011) De praktijk van de kleine kwekers in de aardappelveredeling in Nederland. COGEM, Bilthoven

Lindhout P, Meijer D, Schotte T, Hutten RCB, Visser RGF, van Eck HJ (2011) Towards F1 hybrid seed potato breeding. Potato Res 54(4):301-312. https://doi.org/10.1007/s11540-011-9196-Z

Lommen WJM (2015) How age of transplants from in vitro derived potato plantlets affects crop growth and seed tuber yield after field transplanting. Potato Res 58(4):343-360. https://doi.org/10.1007/s11540-0159305-5 
Lommen WJM (1999) Causes for low tuber yields of transplants from in vitro potato plantlets of early cultivars after field planting. J Agric Sci 133(3):275-275. https://doi.org/10.1017/S002185969900698X

Lommen WJM, Struik PC (1994) Field performance of potato minitubers with different fresh weights and conventional seed tubers: crop establishment and yield formation. Potato Res 37(3):301-313. https://doi. org/10.1007/bf02360523

Mikitzel L (2014) Tuber physiological disorders. In: Navarre R, Pavek MJ (eds) The potato: botany, production and uses. CABI, Boston, pp 237-254

Shaw RH, Buchele WF (1957) The effect of the shape of the soil surface profile on soil temperature and moisture. Iowa State Coll J Sci 32:95-104

Spruijt J, Van der Voort M (2015) Kwantitatieve informatie akkerbouw en vollegrondsgroenteteelt 2015. Praktijkonderzoek Plant en Omgeving (PPO), Wageningen UR, Lelystad

Stockem J, de Vries M, van Nieuwenhuizen E, Lindhout P, Struik PC (2020) Contribution and stability of yield components of diploid hybrid potato. Potato Res 63:345-366. https://doi.org/10.1007/s11540-01909444-X

Stokstad E (2019) The new potato. Science New York 363(6427):574-577. https://doi.org/10.1126/science. 363.6427 .574

Struik PC, Haverkort AJ, Vreugdenhil D, Bus CB, Dankert R (1990) Manipulation of tuber-size distribution of a potato crop. Potato Res 33(4):417-432. https://doi.org/10.1007/BF02358019

Struik PC, Wiersema SG (1999) Seed potato technology. Wageningen Pers, Wageningen. https://doi.org/10. 3920/978-90-8686-759-2

Tadesse M, Lommen WJM, Struik PC (2001a) Development of micropropagated potato plants over three phases of growth as affected by temperature in different phases. NJAS-Wagen J Life Sc 49(1):53-66. https://doi.org/10.1016/S1573-5214(01)80015-4

Tadesse M, Lommen WJM, Struik PC (2001b) Effects of nitrogen pre-treatment of transplants from in vitro produced potato plantlets on transplant growth and yield in the field. NJAS-Wagen J Life Sc 49(1):67-79. https://doi.org/10.1016/S1573-5214(01)80016-6

Taylor CE (1953) The vegetative development of the potato plant. Ann Appl Biol 40(4):778-788

Thomas-Sharma S, Abdurahman A, Ali S, Andrade-Piedra JL, Bao S, Charkowski AO, Crook D, Kadian M, Kromann P, Struik PC, Torrance L, Garrett KA, Forbes GA (2016) Seed degeneration in potato: the need for an integrated seed health strategy to mitigate the problem in developing countries. Plant Pathol 65(1): 3-16. https://doi.org/10.1111/ppa.12439

Tiemens-Hulscher M, Delleman J, Eising J, Lammerts van Bueren ET (2013) Potato breeding. Drukkerij De Swart, Den Haag

Van der Zaag D (1999) Die gewone aardappel. Geschiedenis van de aardappel en de aardappelteelt in Nederland. self-published, Wageningen

Vermeulen P (2012) Kwantitatieve informatie voor de glastuinbouw 2012-2013: Kengetallen voor groenten snijbloemen - pot- en perkplanten teelten. Wageningen UR Glastuinbouw, Bleiswijk

Wiersema SG (1984) The production and utilization of seed tubers derived from true potato seed. University of Reading, Dissertation https://wur.on.worldcat.org/oclc/67707775

Wohleb CH, Knowles NR, Pavek MJ (2014) Plant growth and development. In: Navarre R, Pavek MJ (eds) The potato: botany, production and uses. CABI, Boston, pp 64-82. https://doi.org/10.1079/ 9781780642802.0064

Xie Y, Kristensen HL (2017) Intercropping leek (Allium porrum L.) with dyer's woad (Isatis tinctoria L.) increases rooted zone and agro-ecosystem retention of nitrogen. Eur J Agron 82A:21-32. https://doi.org/ 10.1016/j.eja.2016.09.017

Yamamoto T, Matsuo K, Yamasaki A (2016) Transplant depth of cabbage plug seedlings affects root distribution and anchorage resistance. Sci Hortic 213:144-151. https://doi.org/10.1016/j.scienta.2016. 10.010

Publisher's Note Springer Nature remains neutral with regard to jurisdictional claims in published maps and institutional affiliations. 


\section{Affiliations}

Luuk C. M. van Dijk ${ }^{1,2}$. Willemien J. M. Lommen ${ }^{1}$.

Michiel E. de Vries ${ }^{2}$ - Olivia C. Kacheyo ${ }^{2}$. Paul C. Struik ${ }^{1}$

1 Centre for Crop Systems Analysis, Wageningen University and Research, Bornsesteeg 48, $6708 \mathrm{PE}$ Wageningen, The Netherlands

2 Solynta, Dreijenlaan 2, 6703 HAWageningen, The Netherlands 